
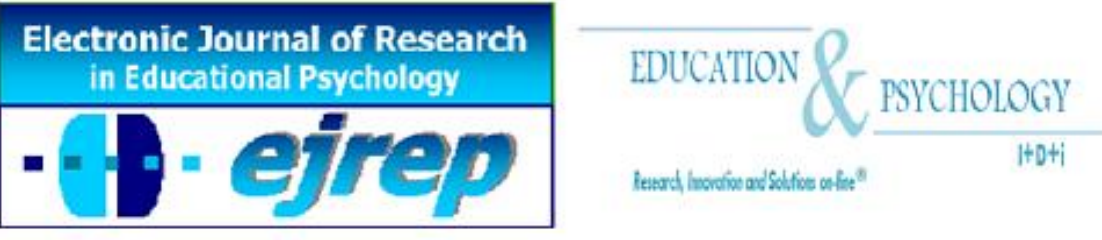

Ilustre Colegio Oficial de Psicología de andalucia oriental

\title{
Students' Perceptions about Teachers' Feedback in a Career Construction: A Study in Vocational Education
}

\section{Martins, D. ${ }^{1}$ \& Carvalho, C. ${ }^{2}$}

${ }^{1} \mathrm{PhD}$ Student in Educational Psychology, Researcher at the Unit for Research and Development in Education and Training, Institute of Education, University of Lisbon.

${ }^{2}$ Assistant Professor and researcher at the Unit for Research and Development in Education and Training, Institute of Education, University of Lisbon.

\section{Portugal}

Correspondence: Carolina Fernandes de Carvalho. Instituto de Educação da Universidade de Lisboa, Alameda da Universidade, 1649-013 Lisboa. Portugal. E-mail: cfcarvalho@ie.ul.pt

(C) Education \& Psychology I+D+i and Ilustre Colegio Oficial de Psicólogos de Andalucía Oriental (Spain) 


\section{Abstract}

Introduction. The idea that feedback is information about the gap between the current and the desired level of performance is largely accepted in the literature. Likewise, it is thought that it has an impact in future beliefs about self, tasks or cognitive strategies. However, the importance that the students give to teacher's feedback, as a guidance practice to develop their own future time perspectives in terms of vocational identity, reveals the need for improvement of this pedagogical practice as a possible new approach for career construction in the 21 st century. The paper main goal is to understand how students, attending courses with vocational curriculum, regard the choice or the decision of a professional future, through the teachers' feedback.

Method. The methodological plan used, in addition to collecting socio-demographic identification data, the Dellas Identity Status Inventory-Occupation and two open questions about students' perceptions of the teachers' feedback. Twenty-eight Portuguese students attending three different courses in the Lisbon metropolitan area, between 15 and 19 years of age, participated in this study.

Results. Results suggest that although students are attending different vocational courses, it seems that most of them are in a Moratorium dimension, showing little or no ability to explore vocational goals.

Discussion and Conclusion. Search for vocational goals can be a way to be adapted to an educational and labour reality and a way to be prepared to face a changing world.

The teachers' feedback comments are understood as motivators, coaches and clarifiers of future perspectives of career construction and development.

Keywords: Teachers' Feedback, Students, Career, Vocational Identity, Vocational Education 


\section{Percepciones de los estudiantes sobre la retroalimentación docente en una construcción de carrera. Un estudio desde la formación profesional}

\section{Resumen}

Introducción. La idea de que el feedback es información acerca de la diferencia entre el nivel actual y deseado de desempeño y que tiene un impacto en el ejercicio futuro es aceptado en la literatura. Sin embargo, la importancia de que los estudiantes dan a los comentarios de los maestros como una práctica de orientación para desarrollar sus propias perspectivas temporales futuras en términos de identidad vocacional revela la necesidad de mejorar esta práctica pedagógica como posible nuevo enfoque para la construcción de la carrera en el siglo 21. El objetivo principal de la investigación fue entender cómo los alumnos, que asisten a cursos con currículo profesional, consideran la elección o la decisión de un futuro profesional, a través de lo feedback de los maestros.

Método. El plan metodológico utilizado incluye, además de la recogida de los datos de identificación socio-demográficas, el Dellas Identity Status Inventory-Occupation y dos preguntas abiertas sobre las percepciones de los estudiantes sobre el feedback de los maestros.Veintiocho estudiantes portugueses que asisten a tres diferentes cursos, del área metropolitana de Lisboa, entre 15 y 19 años de edad, participaron en este estudio.

Resultados. Los resultados sugieren que aunque los estudiantes están asistiendo a diferentes cursos de formación profesional, parece que la mayoría de ellos están en la dimensión Moratorium, que muestran poca o ninguna capacidad de explorar las metas vocacionales.

Discusión y Conclusión. La búsqueda de metas vocacionales puede ser una manera de adaptarse a una realidad educativa y laboral y una manera de estar preparados para enfrentar un mundo en transformación. Los comentarios de feedback de los maestros se entienden como motivadores, entrenadores y clarificadores de las perspectivas futuras y de la construcción y el desarrollo profesional.

Palabras Clave: Feedback de los Maestros, Estudiantes, Carrera, Identidad Vocacional, Educación Vocacional. 


\section{Introduction}

In Portugal, the education policies are base don the benchmarks of the European Union (e.g., European Council, 2006, 2007; UNESCO, 2000) and highlight the importance of formal education for our students in school context for the construction and development of essential skills, in order to prepare them for active life (Carvalho et al., 2008). One of the school aims is to encourage knowledge appropriation, enabling students to become active citizens. Likewise, students should be able to mobilize cultural, scientific and technological knowledge in order to understand reality and be prepared to deal with situations and common problems of daily life (DEB, 2003). The development of competences describes and assumes interaction and convergence between curriculum areas. Thus, teachers are charged with the task of focusing on how individual subject characteristics can be drawn on to foster students' abilities to question reality, identify the required knowledge for dealing with common problems in daily life, and assess the appropriateness of knowledge and procedures.

The research presented here considers those students who are attending vocational courses as a way to promote formal learning opportunities (OCDE, 1989), linking the teachers' feedback as a form of vocational guidance. According to Vega (2009), vocational guidance belongs to the school in general and to the teachers in particular. Teachers are one of the most important agents in vocational education, and in addition to its traditional role, it constitutes, themselves, as essential personalities in the "training and preparing young people for life skills and citizenship" (Mouta \& Nascimento, 2008, p. 87). Besides that, one of the problems in schools is that "the number of people working on vocational guidance is, in most cases, insufficient to meet the demand and to respond effectively to the needs of students (OCDE, 2005, p. 16).

In general, it is the teachers who support and share updated information on the vocational development process (Mouta \& Nascimento, 2008). Indeed, in the opinion of Coimbra (1995), the action of teachers in vocational guidance can be a key in the development of vocational identity, particularly in relation to the creation of opportunities for exploration, relationships and interaction " with the world of formations and the world of work". (p.28). Therefore, on the one hand, teachers' strategies based on vocational guidance allow relationships between teacher and student and, on the other hand, promote the construction of essential personal and social meanings for the development of a vocational identity. This can, in fact, increase the appeal of the development of both vocational identity and expectations regarding 
the student's future as a new approach to meet the needs of the 21 st century in terms of a career construction in a vocational education context (Savickas et al., 2009).

In Portuguese Educational system, vocational education context is a) for students who want to developed knowledge and skills for entry into the world of work with the possibility to further study or b) for students who have not completed de compulsory education. This second possibility is specially designed by the Ministry of Education as well as the Ministry of Labour and Social Solidarity as an alternative pathway for students aged over 15 years. These pathways include the conclusion of the primary education (Portuguese 3rd cycle of basic education), providing dual certification, academic and professional, and allow to these students to further studies, including courses in education and training and apprenticeships (European Commission, 2008). Subsequently in our study the students were attending vocational courses, namely Education and Training for Adults (EFA), which offers a second chance to individuals who left school early or are at risk of early leaving it, and for those who have not had the opportunity to attend it when they were young (Ministry of Labour and Social Solidarity and Education, Portaria n. ${ }^{\circ}$ 230/2008 de 7 de Março). This modality centres the school for vocational and personal development in a perspective of lifelong learning. In addition, for our participants, EFA courses seek to ensure an education and training to allow those who left school early, for have a vocational qualification for a better learning prospect and to facilitate the entry into the world of work (Martins \& Carvalho, 2013e).

In this sense, in this paper we are trying to answer the follow questions: a) Which differences are there in the vocational identity status, according to the vocational EFA courses attended by the students? and b) How do these students perceive their future career through the teachers' feedback?.

According to Hattie and Timperley (2009), "feedback is conceptualized as information provided by an agent (e.g., teacher, peer, book, parent, self, experience) regarding aspects of one's performance or understanding" (p.81). A recent research on meta-analysis said that feedback is "the most powerful influences on achievement" (Hattie, 2009, p.173). In the model of feedback proposed by Hattie and Timperley (2007), the importance of feedback is recognized in the formative process of questions like "where am I going?", "How am I going?" and "where to next?". In this sense, feedback integrates the temporal flow of personal and formative experiences, as the parties of past, present and future (Zimbardo \& Boyd, 1999). This temporal flow seems to have an effect on students' construction of meaning about 
their own experience at school and themselves as students. By negotiating meaning about their own experience as school students they are also negotiating an identity. In this sense, this negation during school trajectories will help students in choices and decisions for a future career (Savickas, 1997/1998). Consequently, feedback acquires a fundamental role in the development of vocational guidance. Thus, the role of teachers' feedback is an effective resource in the creation of opportunities for exploration, interaction and relationship in the development of students' future career perspectives (Coimbra, 1995; Martins \& Carvalho, 2013a; Taveira, 2000; Vega, 2009).

Time perspective of the future, particularly related to academic and vocational pathways, are good predictors of students investment in vocational issues, concretely because this investment is part of the oriented vocational guidance for a future career. It seems, moreover, to be associated with several factors related to career, as career goals, career choices and student motivation (Peetsma, 2000).

\section{Teachers' feedback as a vocational guidance practice}

According to the educational literature, feedback reveals itself as an important aspect in the relationship between teacher and student (Black \& Wiliam, 1998; Black, Harrison, Lee, Marshall, \& Wiliam, 2002; Hattie, 2009). The feedback, in its cognitive dimension, can be understood as the provision of information by an agent on aspects of knowledge or performance of another person (Hattie \& Timperley, 2007), in this sense, with a clear impact on students learning performance and self-regulated learning (Kluger \& DeNisi, 1996, 2004; Zimmerman \& Schunk, 2001, 2007).

Hattie and Timperley (2007), in their theory model of feedback recognized that it is different effects levels including "the level of task performance, the level of process of understanding how to do a task, the regulatory or metacognitive process level, and/or the self or personal level (unrelated to the specifics of the task)" (p. 86). The theme arising from this model centred in major four levels that can be understood and used as a sequence strategy for students' achievement and self-assessment. It is important "assure that feedback is targeted at students at the appropriate level, because some feedback is effective in reducing the discrepancy between current understandings and what is desired, and some is ineffective" (p.86). For instance, these authors argue that the feedback about the person that is directed to the "self" is the least effective, the feedback of process (understanding how to do a task) and the regula- 
tory feedback "are powerful in terms of deep processing and mastery of tasks" (p. 90). Finally, the feedback of task performance "is powerful when the task information subsequently is useful for improving strategy processing or enhancing self regulation" (p.91).

Moreover Hattie (2009) considers that the feedback is not, only, given by teachers on students' performance information. Students also provide feedback to teachers (eg.: for their mistakes, the misconceptions that reveal, the motivation that show). The feedback that students give to the teachers helps them to make learning visible, in other words, feedback is the result of a performance and in a classroom, are not only students who show it.

On the other hand, the affective dimension of the feedback is also very important, as it appears to have a role in the construction of the identity of the student in providing information that enables students to create interpretations about themselves, including vocational identity, about others and about school. In this sense, the identity originates ways of being, acting, and relating to educational providers and the practices of the classroom but also, have influence on the decisions that the student is taking in the school (Freire, Carvalho, Freire, Oliveira \& Azevedo 2009), as well as the positions they will occupy in the school community (Holland, Lachiotte, Skinner \& Cain, 1998; Hand, 2006).

Therefore, the identity of the student influences the way of being, acting and communicating, influence in turn the vocational guidance behavior of the teacher. Therefore, the teachers' feedback practices contribute to the classroom environment and also to the students' academic commitment in their vocational pathways. In turn, the teachers' feedback practices that do not contribute to the classroom environment, and do not promote the development of knowledge and skills, or do not establish a teacher-student relationship based on respect and safety, may, adversely, affect the student's academic commitment, as well as, their vocational decisions (Schussler, 2009). The student's academic commitment results from the possibility of satisfying some basic psychological needs such as the feeling of competence, establishing relationships, security and the feeling of autonomy (Verkuyten \& Thijs, 2009).

Indeed, in the opinion of Coimbra (1995), the teachers' action in educational guidance practices, as the teachers feedback, is the key in the development of students vocational identity, particularly in relation to the creation of opportunities for exploration, relationships and interaction "with the training world and the world of work "(p. 28). It is in this sense that the educational field of guiding, the teacher's feedback acquires a fundamental role in the development of practical vocational guidance and, consequently, in the construction and develop- 
ment of vocational identity, regarding to promoting choices and decision making for future employment or profession (Savickas, 1997/1998). In general, educational guidance, and in particular the teachers' feedback, effectively, is a way of preparing the construction and development of vocational choices and life plans on the students' academic trajectories (Taveira, 2000; Vega, 2009).

\section{Aims of the study}

The papers' main aim is to understand how students (attending courses with vocational curriculum) regard the choice or the decision of a professional future, through the teachers' feedback. Specifically, we wished to (a) Evaluate the characteristics of students' vocational identity, according to age and the courses attended, and to (b) Know students' perceptions about the teachers' feedback in the development of time perspectives of a future career.

\section{Method}

\section{Participants}

Our participants were attending vocational education in EFA courses modality. These students were enrolled in one of three courses: Waiter, Kitchen and Hotel Maintenance Operator (HMO). These three courses were equivalent to the $7^{\text {th }}, 8^{\text {th }}$ and $9^{\text {th }}$ grades of compulsory education. A total of 28 male students participated in the study. Their ages ranged between 15 and 19 years of age $(M=16.96$ and $S D=1.105)$.

\section{Instruments}

The methodological plan used included, in addition to collecting sociodemographic identification data, the Dellas Identity Status Inventory-Occupation (DISI-O; Dellas \& Jernigan, 1981, adapted to Portuguese population by Taveira, 1986) and two open questions about students perceptions of the teachers' feedback.

The DISI-O scale has already been adapted to the Portuguese population by Taveira (1986; Taveira \& Campos, 1987). It contains 35 items and allows student ascription of one of the following types of identity status: achiever, moratorium, foreclosure, diffusion-diffusion and diffusion-luck. This division is similar to the one developed by James Marcia (1966), ex- 
cept for the subdivision of diffusion. For this situation we followed the convention of Dellas and Jernigan (1981) of separating diffused-diffused and diffused-luck into two different statuses of diffusion. The 35 items are organized in seven sets of five.

Regarding the reliability of the instrument, the DISI-O scale adapted in Portugal showed very satisfactory results approximate to the original study of Dellas and Jerningan (1981). The analysis results (coefficient alphas) revealed the existence of five dimensions on the DISI-O scale: Achiever, Moratorium, Foreclosure, Diffusion-Diffusion and DiffusionLuck $(.89, .74, .85, .82, .62$, respectively)

According to Taveira and Campos (1987), each item in a set stands for one of the five identity status categories with Likert responses coded 5 for "Totally According with Me" through 1 "Totally Disagree with Me". "Belonging to a statute is decided when the answer according to me is, totally, attributed to, at least, four of the seven statements of the own status" (p. 56)

\section{Procedure}

In an initial phase of our methodological plan, and in order to answer our first research question, "Which differences are in the vocational identity status according to the vocational courses attended by the students?", we used a sociodemographic sheets to establish the ages and courses attended by these young people and the Dellas Identity Status Inventory Occupation scale (DISI-O, Dellas \& Jernigan, 1981) to understand how vocational identity of the young participants was being resolved.

Trying to find the answer of our second research question "How students perceive their future career through the teachers' feedback?", students also answer two open questions: (a) Do you think it is important that teachers give you feedback about your performance in the course?; (b) From the teachers' feedback that you receive, this course is the one you think that will help you to find a future job?. These questions are of course open to interpretation, depending of the perceptions that the students have of the teachers' feedback in the development of their future perspective of career construction.

Filling in the instruments was supervised by the first author of this paper in the courses above mentioned. This task took place in the normal hours of the training courses and the students collaborated voluntarily. 


\section{Data analysis}

Statistical analyses employed SPSS 20.0 for Windows. Concretely, it was conducted a one-way ANOVA, in order to verify if there were significant differences in the mean scores on the DISI-O dimensions, according to the courses attended. The information collected from the two open questions were analyzed by a content analysis process (Bardin, 2011). The unit of analysis was the students' answers and the emergent categories from this content analysis reveal the students perceptions of the teachers' feedback on their future vocational plans.

\section{Results}

Trying to find an answer to our first research question, "Which differences are there in the vocational identity status according to the courses attended by the students?", Tables 1 and 2 show the data collected through the sociodemographic questionnaire and the DISI-O scale. Table 2 also presents some of the descriptive statistical analysis results of the one-way ANOVA. For this analysis we used the Statistical Package for Social Sciences (SPSS) version 20.

\section{Students' vocational identity according to the courses attended}

Table 1 shows a total of 28 students, with ages ranging between 15 and 19 years old, participating in this initial research. These students were attending three different vocational courses, namely: Kitchen, Waiter and Hotel Maintenance Operator. These courses, in addition to conferring a professional qualification, also confer equivalence to the primary education, $3^{\text {rd }}$ cycle from $7^{\text {th }}$ to $9^{\text {th }}$ grades of the Portuguese Basic Education system.

Table 1. Descriptive Statistics of age and courses

\begin{tabular}{|c|c|c|c|c|c|}
\hline Courses & $\mathrm{N}$ & & & Age & \\
\hline Kitchen & 9 & $\begin{array}{c}M \\
16,78\end{array}$ & $\begin{array}{c}S D \\
(1,093)\end{array}$ & $\begin{array}{c}\text { Minimum } \\
15\end{array}$ & $\begin{array}{c}\text { Maximum } \\
18\end{array}$ \\
\hline Waiter & 10 & 16,44 & $(1,130)$ & 16 & 19 \\
\hline $\begin{array}{c}\text { Hotel Mainten } \\
\text { Operator }\end{array}$ & 9 & 17,60 & $(0,843)$ & 15 & 18 \\
\hline Total & 28 & 16,96 & $(1,105)$ & 15 & 19 \\
\hline
\end{tabular}


Looking at Table 1 it is possible to verify that the mean ages and the number of the students in attendance of the courses are very close together. On average, the youngest participants were enrolled in the waiter course; the oldest attended the Hotel Maintenance Operator course.

In Table 2 we present the status means of the results obtained through the DISI-O scale. Through this scale it was possible to evaluate resolution modes of vocational identity of our participants in the attendance of the three vocational courses.

Table 2. Descriptive Statistics of DISI-O Dimensions by courses

\begin{tabular}{cccccc}
\hline Courses & & \multicolumn{4}{l}{ DISI-O Dimensions } \\
\hline & Achiever & $\underline{\text { Moratorium }}$ & $\underline{\text { Foreclosure }}$ & $\frac{\underline{\text { Diffusion- }}}{\text { Diffusion }}$ & $\frac{\underline{\text { Diffusion- }}}{\underline{\text { Luck }}}$ \\
& $M(S D)$ & $M(S D)$ & $M(S D)$ & $M(S D)$ & $M(S D)$ \\
Kitchen & $24,66(3,240)$ & $26,87(3,563)$ & $22,37(3,961)$ & $24,33(2,915)$ & $22,66(3,535)$ \\
Waiter & $25,22(6,057)$ & $27,88(6,508)$ & $22,44(6,894)$ & $24,33(6,041)$ & $22,44(4,927)$ \\
Hotel Maintenance & & & & & \\
Operator & $26,22(5,238)$ & $27,11(4,044)$ & $20,66(3,500)$ & $22,44(5,659)$ & $21,77(6,704)$ \\
Total & $25,37(4,836)$ & $27,30(4,747)$ & $21,80(4,923)$ & $23,70(4,952)$ & $22,29(5,029)$ \\
\hline
\end{tabular}

Looking at Table 2, it is possible to read, in terms of means, results that students position themselves in Moratorium status. There is slight evidence that the students in the Hotel Maintenance Operator course are in Achiever status and the students in the other two courses, kitchen and waiter, are positioned in Foreclosure and Diffusion statutes.

\section{Perceptions of students about the teachers' feedback}

From our second research question, "How students perceive their future career through the teachers' feedback?", a total of 28 students answered to the following two open questions:

a) Do you think it is important that teachers give you feedback about your performance in the course?

b) From the teachers' feedback that you receive, this course is the one you think that will help you to find a future job? 
The categories presented in Tables 3 and 4 result from the students' answers and justifications of two open questions about students perceptions of the teachers' feedback. These emergent categories are constructed according to Bardin (2011) content analysis. The emergent categories of the first question "Do you think it is important that teachers give you feedback about your performance in the course? are presented in Table 3 and the ones from the second question " From the teachers' feedback that you receive, this course is the one you think that will help you to find a future job?" are presented in Table 4. In Table 3, it is possible to read that all the participant students consider the teachers' feedback important to their performance in the course. All justifications considered the teachers' feedback as a vocational guidance.

Table 3. Emergent Categories: "Do you think it is important that teachers give you feedback about your performance in the course?"

\begin{tabular}{llr}
\hline Category & \multicolumn{1}{c}{ Answer } & \multicolumn{1}{c}{ Frequency } \\
& "Yes, help us to understand our performance" & 9 \\
& "Yes, because it is always a good opinion, because the & \\
Vocational & $\begin{array}{l}\text { teachers know us and the professional opportunities of the } \\
\text { course " } \\
\text { Guidance } \\
\end{array}$ & 3 \\
& $\begin{array}{l}\text { "Yes, because I have to know my skills and what way to } \\
\text { "Yes, just so I know what I have to improve in order to be a } \\
\text { good professional" }\end{array}$ & 6 \\
Total & & $\underline{28}$ \\
\hline
\end{tabular}

Looking at Table 4, it is possible to see that the majority of students do not show a real interest in the course. However there are some students who consider teachers feedback as needed to follow the course.

Table 4. Emergent Categories:"From the teachers' feedback that you receive, this course is the one you think that will help you to find a future job?"

\begin{tabular}{clr}
\hline Category & \multicolumn{1}{c}{$\begin{array}{c}\text { Answer } \\
\text { "Yes, when I joined this training, I felt that this was } \\
\text { the right course" }\end{array}$} & $\begin{array}{r}\text { Frequency } \\
\text { Engagement } \\
\text { in the course } \\
\begin{array}{c}\text { "Yes, when teacher praises me and says that I will be a } \\
\text { good professional. That gives me more desire to fo- } \\
\text { llow the course" }\end{array}\end{array}$ \\
$\begin{array}{c}\text { Disinterest in the } \\
\text { course }\end{array}$ & "No, because the course has nothing to do with me" \\
$\begin{array}{c}\text { Indecision in the } \\
\text { course } \\
\text { Total }\end{array}$ & "I don't know... it is too early" & 3 \\
\end{tabular}




\section{Discussion}

In Table 1 and 2 we present some of the descriptive statistical elements of the test one-way ANOVA, specifically the mean ages of the 28 participants and the means of the DISI-O dimensions all presented by the vocational courses attended by the participants. We conducted a one-way ANOVA, in order to verify if there were significant differences in the mean scores on the DISI-O dimensions, according to the courses attended. It is possible to read in Table 1 that the mean ages of the 28 young participants are 16,96 years $(\mathrm{SD}=1,105)$.

In general, in terms of status means, the results seem similar to previous works (e.g., Dellas \& Jernigan, 1981; Martins \& Carvalho, 2013a; Taveira, 1986, 2000; Taveira \& Campos, 1987), the participants tend to occupy the stage of Moratorium identity, which is characterised by young people who are living a period of exploration of the issues of identity while expressing difficulty in making choices. Although the results seem to indicate that most of the participating students occupy the Moratorium identity status, there is slight evidence that some of the students, attending the Hotel Maintenance Operator course are in Achiever identity status and the students in the other two courses, Kitchen and Waiter, are more positioned in Foreclosure and Diffusion statutes.

The Achiever Identity status is characterized by designating those experiencing a period of exploration and therefore investment in vocational plans may have occurred. Opposite, the Diffusion identity statutes reveal poor investment or even absence of investment in vocational plans (Taveira \& Campos, 1987). Taking into account some previous studies (e.g., Marcia, 1966; Meeus, 1993; Taveira, 1986, 2000; Taveira \& Campos, 1987), as age increases the individuals have a clearer perception of investment in relation of vocational plans and options. In the study of Taveira and Campos (1987) the critical period for changes in vocational identity takes place from 18 years of age. In this sense, as shown in Table 1, our participating students who attended the Hotel Maintenance Operator course were the oldest $(\mathrm{M}=17,60 ; \mathrm{SD}=, 843)$ and perhaps so are those who positioned themselves in Achiever identity status.

In this study vocational gender differences were not considered, since our participants were all male. Although it would have been a challenge for us to investigate this hypothesis, some studies (e.g., Taveira \& Campos, 1987) do not indicate any significant differences between both genders in the statutes of identity. In this way, for the analysis of variance tests 
one-way ANOVA, the subjects were divided into three groups according to their courses (Kitchen, Waiter, Hotel Maintenance Operator). No statistically significant differences were observed among the courses in any of the identity dimensions. Planned post hoc analyses (Tukey HSD) were, therefore, not conducted.

Although our participants were attending vocational courses and some of them may even have initiated career exploration, they do not reveal the ability to make choices or elaborate coherent projects for a time perspective involving a future career. It is perhaps in this way that in the second analysis of students' answers from the two open questions, it is possible to understand that the great majority of them consider teachers' feedback a consequent practice, since teachers are seen as experienced professionals and experts in the school trajectories of their students (see Table 3). As such, the feedback comments are understood as motivators, and clarifiers of future perspectives of career construction and development (see Table 4).

In this sense, they consider that teachers provide effective feedback, helping them to better identify their own individual skills (see Table 3). In this way, students perceive teachers as experts who monitor problems and provide relevant and useful feedback. The feedback can encourage students to better perceive their future (Hattie, 2003). Although our participants consider the teachers' feedback as important, at the same time most of them do not consider the teachers' feedback encouraging enough to regard a future career, because they do not feel engaged in the course attended (see Table 4: "...because the course has nothing to do with me") or simply because of feelings of undecidedness, they consider it is "... too early" to reflect on this particular issue. However, 10 out of the 28 students think that the teachers' feedback is motivating.

As in the previous study of Hattie (2003, p.2), "It is what teachers know, do, and care about which is very powerful" in the achievement process, because teachers are the ones who are most able to monitor, understand, and interpret students with more insight. And "as a consequence they seek and provide more and better feedback in light of this monitoring" (p.8). In this sense, we emphasize that in a society where teachers have a strong influence on the personal and social development of their students, feedback is an important component of the pedagogical process, which provides support for the development of the perception of a future career (Brookhart, 2008). For instance, Hattie' (2003) opinion highlights that the teachers make a difference, once they "have powerful and sensationally positive effects" on their students achievement (p.3). These experts and experienced professionals with higher quality 
teaching and higher expectations (ibidem) make the difference not only in students learning by promoting appropriate topics to teach, but also in giving the useful information and making time for the feedback (Fisher \& Frey, 2012), concretely in vocational aspects of students trajectories, such as areas or vocational courses that they can attend, taking into account the characteristics that they exhibit, either as students or as individuals.

Courses, especially those with the vocational curriculum, should be chosen according to future prospects outlined by students, but unfortunately in this case most students enrolled in the courses without any other options or an interview for screening guidance or vocational plans. Maybe that is why, according to our results, it is possible to understand the importance that the students give to teacher feedback as a guidance practice to develop their vocational identity.

One of the advantages of feedback is that it is aligned with many of the best practices associated with planning and development the students' vocational choices and life projects (Brookhart, 2008; Fisher \& Frey 2007; Taveira, 2000; Vega, 2009). In Hattie's opinion (2003, p. 8) feedback is "the most powerful single moderator that enhances achievement". Feedback has generally positive effects in classroom interventions as an educational guidance for promoting the development of future career perspectives (Hattie, 2009). This guidance practice in a school context has numerous advantages in personal and social training of our students, since, for many of them, school can be an unique opportunity to support the process of construction and development of vocational identity, allowing students access to vocational training and, thus, facilitating the transition to active life (Taveira, 2000, 2004).

In the opinion of Savickas (2005, p.49), "the goal of the school-to-work transition is that emerging adults learn to contribute to society by fitting their personalities into suitable work roles. The social expectation that adolescents seek occupations congruent with their abilities and interests is communicated to them in the form of vocational development tasks". This transition between school and a future career, in addition to helping students' in their vocational choices, promotes social inclusion, helping them in their integration in the workforce.

\section{Final Considerations}

The role of teacher's feedback in the development of students' learning is widely acknowledged and relatively well documented (e.g. Hattie, 2003; Hattie \& Timperley 2007; Hattie, 2009). However, the idea that teachers' feedback supports and promotes the develop- 
ment of students' vocational identities needs more work to be done to integrate research on vocational guidance and learning outcomes.

It is known that adolescents are able to formulate hypotheses, mentally exploring different alternatives and taking into account the views of others while they develop metacognitive abilities (Nurmi, 1991). When young people formulate future objectives, they internalize the importance that behaviors have in enabling them to reach their goals, which leads to the recognition of the importance of a vocational orientation or choice to succeed in their lives (Jones \& Brown, 2005).

In Western society, a future perspective is considered adaptive (Zimbardo \& Boyd, 1999) since it meets the requirements that society establishes and, consequently, is culturally valued. In this way, the development of a temporal future perspective can be important to achieve educational and vocational goals. It is important to encourage young people to develop their future time perspective, to formulate objectives targeted to their interests in order to develop an internal structure that places individual identity in relation to others and to what they wants to be, or do, in a future career.

\section{Acknowledgements}

This study is part of a broader project, entitled Feedback, Identity and Trajectories in Education: Dynamics and Consequences (PTDC/CPE-PEC/121238/2010), where a study is being developed on the "Development of vocational identity of institutionalized young's in Portuguese educational centers". This project is funded by the Foundation for Science and Technology (FCT), ongoing at the Institute of Education of the University of Lisbon, Portugal. Thanks to the participating students and their educational institutions; members of project, especially Professor Joseph Conboy, and the Foundation for Science and Technology for the funding the project (PTDC/CPE-PEC/121238/2010) and consequently this work. 


\section{References}

Bardin, L. (2011). Análise de Conteúdo. [Content Analysis.] Lisboa: Edições 70

Black, P., \& Wiliam, D. (1998). Inside the black box: Raising standers through classroom assessment. London: School of Education, King’s College.

Black, P., Harrison, C; Lee, C. Marshall, B., \& Wiliam, D. (2002). Working inside the black box. Assessment for learning in the classroom. London: GL Assessment.

Blustein, D. L., \& Noumair, A. A. (1996). Self and Identity in Career Development: Implications for Theory and Practice. Journal Of Counseling \& Development, 74(5), 433-441.

Brookhart, S. M. (2008). How to Give Effective Feedback to your Students. Virginia USA: Association for Supervision and Curriculum Development.

Carvalho, C., Freire, S., Baptista, M., Freire, A., Azevedo, M., \& Oliveira, T. (2008). Changing practices, changing identities: a study with students at risk of educational exclusion. In: A. Ross (Ed), Reflecting on Identities. London: CiCe.

Coimbra, J. L. (1995). Os Professores e a Orientação Vocacional. [Teachers and the Vocational Guidance.] Noesis, 26-29. Porto: FPCE - Universidade do Porto.

DEB (2003). The National Curriculum for basic education: essential competences. Retrieved from http://www.fne.pt/files_old/curriculo_nacional_ens_basico/general_competences.pdf.

Dellas, M., \& Jernigan, L. P. (1981). Development of an objective instrument to measure identity status in terms of occupation crisis and commitment. Educational \& Psychological Measurement, 41, 1039-1050.

European Commission (2008). Vocational Guidance Education in Full-Time Compulsory Education in Europe. Brussels: EURYDICE. Retrieved from http://hdl.voced.edu.au/10707/66228.

European Council (2006). Progress towards the Lisbon objectives in education and training. $\begin{array}{llll}\text { Brussels: } & \text { European } & \text { Council. } & \text { Retrieved }\end{array}$ http://ec.europa.eu/education/policies/2010/doc/progressreport06.pdf

European Council (2007). Schools for the 21st century. Brussels: European Council. Retrieved from http://ec.europa.eu/education/school21/consultdoc_en.pdf 
Fisher, D., \& Frey, N. (2007). Checking for understanding: formative assessment techniques for your classroom. Virginia USA: Association for Supervision and Curriculum Development.

Fisher, D., \& Frey, N. (2012). Making Time for Feedback. Feedback for Learning, 70(1), 4246.

Freire, S.; Carvalho, C.; Freire, A.; Azevedo, M., \& Oliveira, T. (2009). Identity construction through schooling: listening to students voices. European Educational Research Journal, 8(1), 80-88.

Hand, V. (2006). Operationalizing Culture and Identity in Ways to Capture the Negotiation of Participation across Communities. Human Development, 49, 36-41.

Hattie, J. (2003). Teachers Make a Difference. What is the research evidence? Australian Council for Educational Research Annual Conference on: Building Teacher Quality. Australia: University of Auckland.

Hattie, J., \& Timperley, H. (2007). The Power of Feedback. Review of Educational Research, 77(1), 81-112. doi:10.3102/003465430298487

Hattie, J. (2009). Visible Learning: a synthesis of over 800 meta-analises relating to achievement. London and New York: Routledge.

Holland, D., Lachiotte, W. Jr., Skinner, D., \& Cain, C. (1998). Identity and agency in cultural worlds. Cambridge: Harvard University Press.

Jones, J. M., \& Brown, W. T. (2005). Any Time is Trinidad Time! Cultural Variations in the Value and Function of Time. In A. Strathman \& J. Joireman (Eds.), Understanding behavior in the context of time: theory, research, and application. London: Psychology Press.

Kluger, A. N., \& DeNisi, A. (1996). The effects of feedback interventions on performance: Historical review, a meta-analysis and a preliminary feedback intervention theory. Psychological Bulletin, 119, 254-284.

Kluger, A. N., \& DeNisi, A. (2004). Feedback Interventions: Towards the Understanding of a Double-Edged Sword. In T. F. Oltmanns and R. E. Emery (Eds.). Current Directions in Abnormal Psychology. Upper Saddle River, NJ: Pearson Education. 
Marcia, J. E. (1966). Development and validation of ego-identity status. Journal of Personality and Social Psychology, 3(5), 551-558. doi:10.1037/h0023281

Martins, D., \& Carvalho, C. (2012a). O discurso orientador dos professores no desenvolvimento da identidade vocacional: vozes de alguns jovens do ensino professional [The guiding teachers' discourse in the development of vocational identity: voices of some young people in vocational education]. In Atas do $12^{\circ}$ Colóquio Internacional de Psicologia e Educação-Educação, Aprendizagem e Desenvolvimento: Olhares Contemporâneos Através da Investigação e da Prática, Lisboa, 21-23 Junho 2012 (pp.1257-1270) [Proceedings of the $12^{\text {th }}$ International Conference of Psychology and Education- Education, Learning and Development: Perspectives Through Contemporary Research and Practice (pp. 1257-1270), Lisbon, $21^{\text {st }}-23^{\text {rd }}$ June 2012]. Lisboa: ISPA-Instituto Universitário.

Martins, D., \& Carvalho, C. (2012b). The role of feedback from teachers' in the perspective of future development of young's career attending courses EFA and PIEF. In Proceedings of the First International Conference in Time Perspective: Converging Paths in Psychology Time Theory and Research, Coimbra, 5-8 September, 2012 (pp. 130-131). Coimbra: University of Coimbra.

Martins, D., \& Carvalho, C. (2013a). Teacher's Feedback and Student's Identity: An example of Elementary School Students in Portugal. Procedia - Social and Behavioral Sciences, 82, 302 - 306. doi: 10.1016/j.sbspro.2013.06.265

Martins, D., \& Carvalho, C. (2013e). Curriculum: an opportunity to develop the young's identity? In Proceedings of European Conference on Curriculum Studies. Future Directions: Uncertainty and Possibility, Braga, 18th-19th October 2013 (theme 6 -pp.1-7). Braga: Institute of Education of the University of Minho.

Meeus, W. (1993). Occupational identity development, school performance, and social support in adolescence: findings of a Dutch study. Adolescence. 28(112), 809-18.

Mouta, A., \& Nascimento, I. (2008). Os (novos) interlocutores no desenvolvimento vocacional de jovens: Uma experiência de consultoria a professores. [The (new) interlocutors in youngs' vocational development: An experience of teachers consultancy.] Revista Brasileira de Orientação Profissional, 9(1), pp. 87-101. 
Nurmi, J.E. (1991). How do adolescents see their future? A Review of the development of future orientation and planning. Developmental Review. 11(1), 1-59. doi:10.1016/02732297(91)90002-6

OCDE (1989). O Ensino na Sociedade Moderna. [The Teaching in Modern Society.] Porto: Edições ASA

OCDE (2005). Orientação Escolar e Profissional. Guia para Decisores. [Educational and Vocational Guidance. Guide for Decision Makers.] Lisboa: Direção Geral de Inovação e Desenvolvimento Curricular e Instituto de Orientação Profissional. Recuperado de http://www.iccdpp.org/Portals/1/CG\%20HB\%20PT\%20Orient.Escolar_guia_para_deci sores.pdf

Peetsma, T. (2000). Future time perspective as a predictor of school investment. Scandinavian Journal of Educational Research, 44(2), 177-192. doi:10.1080/00313830050046250

Ministry of Labour and Social Solidarity and Education. Portaria $n .^{\circ}$ 230/2008 de 7 de Março.

Savickas, M. L. (1997/1998) New developments in career theory and practice. Cadernos de Consulta Psicológica, (13-14), 15-19.

Savickas, M. L. (2005). The Theory and Practice of Career Construction. In S. D. Brown and R. W. Lent (Ed), Career Development and Counseling: Putting Theory and Research to Work. Hoboken, NJ: John Wiley \& Sons.

Savickas, M., Nota, L., Rossier, J., Dauwalder, J., Duarte, M., Guichard, J., Soresi, S., Esbroeck, R., \& Vianen, A. (2009). Life designing: A paradigm for career construction in the 21st century. Journal of Vocational Behavior, 75, 239-250.

Schussler, D. (2009). Beyond Content: How Teachers Manage Classrooms to Facilitate Intellectual Engagement for Disengaged Students. Theory Into Practice, 48(2), 114 -121. doi:10.1080/00405840902776376

Taveira, M. C. (1986). Identidade e desenvolvimento vocacional nos jovens. [Identity and young's vocational development.] Dissertação Tese de Mestrado. Porto: Universidade do Porto. 
Taveira, M. C., \& Campos, B. P. (1987). Identidade Vocacional de Jovens: Adaptação de uma Escala (DISI-O). [Young's Vocational Identity: Adaptation of a Scale (DISI-O).] Cadernos de Consulta Psicológica, 3, 55-67.

Taveira, M. C. (2000). Exploração e Desenvolvimento Vocacional de Jovens: Estudo sobre as Relações entre a Exploração, a Identidade e a Indecisão Vocacional. [Exploration and Youngs Vocational Development: Study on the Relationship between Exploration, Identity and Vocational Indecision.] Tese de doutoramento publicada. Braga: Centro de Estudos em Educação e Psicologia, Instituto da Educação e Psicologia da Universidade do Minho.

Taveira, M. C. (2004). Os serviços de desenvolvimento vocacional em Portugal: algumas notas-estímulo para reflexão. [The vocational development services in Portugal: some notes stimulus for reflection.] Psychologica, Extra-Série, 213-234.

UNESCO (2000). Education for All Forum. Paris: UNESCO Retrieved from http://unesdoc.unesco.org/images/0012/001200/120058e.pdf

Valente, M.O., Conboy, J., \& Carvalho, C. (2009). Student voices on how engagement is influenced by teacher's communication of evaluation results. European Conference on Educational Research. Vienna.

Vega, L. S. (2009). Orientación educativa e intervención psicopedagógica- Cambian los tiempos, cambian las responsabilidades profisionales. [Educational Guidance and psychoeducational intervention- Times change, change profisional responsibilities.] Madrid: Ediciones Prirámide.

Verkuyten, J., \& Thijs, M. (2009). Students' Anticipated Situational Engagement: The Roles of Teacher Behavior, Personal Engagement, and Gender. The Journal of Genetic Psychology, 170(3), 268-286. doi: 10.1080/00221320903218323

Zimbardo, P. G., \& Boyd, J. N. (1999). Putting Time in Perspective: A Valid, Reliable Individual-Differences Metric. Journal of Personality \& Social Psychology, 77(6), 12711288 .

Zimmermann, B.J. \& Schunk, D.H. (Eds). (2001). Self-regulated learning and academic achievement: Theoretic perspectives. Mahwah, NJ: Lawrence Erlbaum.

Zimmermann, B.J. \& Schunk, D.H. (Eds). (2007). Motivation and self-regulated learning: Theory, research and applications. Mahwah, (NJ/London): Lawrence Erlbaum. 
Martins, D. \& Carvalho, C.

[This page intentionally left blank] 